Available online at $\quad$ http://www.jfas.info

\title{
DECOLORIZATION OF REACTIVE RED-120 BY USING MACROFUNGUS AND MICROFUNGUS
}

\author{
N. N. Ibrahim ${ }^{1, *}$, S. A. Talib ${ }^{2}$, H. N. Ismail ${ }^{3}$ and C. C. Tay ${ }^{1,2}$ \\ ${ }^{1}$ Faculty of Applied Science, Universiti Teknologi MARA, 40450 Shah Alam, Selangor, \\ Malaysia \\ ${ }^{2}$ Faculty of Civil Engineering, Universiti Teknologi MARA, 40450 Shah Alam, Selangor, \\ Malaysia \\ ${ }^{3}$ Faculty of Applied Science, Universiti Teknologi MARA, 35400 Tapah, Perak, Malaysia
}

Published online: 10 November 2017

\begin{abstract}
The objectives of the study are to investigate the growth of Aspergillus sp. and Pleurotus sp. and decolorization of Reactive Red - 120 in Minimal Salt Solution (MSS). The growths of fungi were measured every 3 days by using spectrophotometer at $540 \mathrm{~nm}$. For decolorization, the fungi were cultured in $10 \mathrm{mg} / \mathrm{L}$ and $20 \mathrm{mg} / \mathrm{L}$ of dye concentration. Furthermore, $\mathrm{pH}$ of 5, 7 and 9 were used to determine the optimum $\mathrm{pH}$ for dye decolorization. The $10 \mathrm{mg} / \mathrm{L}$ concentration and $\mathrm{pH} 5$ were chosen as optimum conditions with the maximum performance of reactive dye decolorization ranging of $60 \%-70 \%$. The Aspergillus sp. was more efficient to decolourize synthetic dye Reactive Red - 120 when compared to Pleurotus sp. This study contributes to the knowledge of mycoremediation and product of mycoremediation kit that could be developed and applied in industry.
\end{abstract}

Keywords: aspergillus sp.; dye decolorization; mycoremediation; pleurotus sp.; reactive red 120 ; synthetic dye.

Author Correspondence, e-mail: nasrulnafis94@gmail.com

doi: http://dx.doi.org/10.4314/jfas.v9i6s.11 


\section{INTRODUCTION}

Synthetic dyes are extensively used in industries, such as textile dyeing, paper printing and leather coloring. The effectiveness in decolorization is a challenge for industries wastewater treatment systems. Current physico-chemical treatment methods such as adsorption, chemical degradation, photo-catalysis and ozonation are not effective in removal of low concentration colored pollutant and expensive. There is a great potential for development of microbiological decolorization systems with efficient total color removal [1]. Therefore, an alternative biological method of bioremediation technology is addressed. Bioremediation uses living organisms for degradation processes that leads to white technology. Apart from bacteria, fungi are also involved in this research area.

Mycoremediation is the use of fungi that are capable in breaking down the large molecules into smaller molecules for plant utilization [2]. The most studied fungus is the white rot fungus Phanerochate chrysosporium in decolorization of various dyes. In another study, the fungus Trichoderma harzianum has also been reported to degrade textile dyes, Congo red, Acid red, Basic blue, Bromophenol blue and Direct green [3]. This is due to enzymes involved in lignin degradation, such as lignin peroxidase (Lip), manganese peroxidase (MnP) and laccase [4-5].

The use of macrofungi species with fruiting body in remediation involve genera Pleurotus, Bjerkandera, Trametes, Polyporus and Phellinus. Meanwhile, microfungi species of the genera Aspergillus, Trichoderma, Penicillium and Rhizopus have been investigated [4, 6-8]. Involved fungi in decolorizaiton of dye wastewater are classified into two groups according to their life states: living cells biodegrade and biobsorpt dyes and dead cells (fungi biomass) adsorb dyes. For living cells, the major mechanism is biodegradation depending on produced enzymes and mineralization of dyes. For dead cells, the mechanism is biosorption, which involves physico-chemical interactions such as adsorption, deposition and ion exchange [9]. However, there is lack of study in comparing macrofungi and microfungi in Reactive Red 120 decolorization.

In the present work, decolorization of synthetic dyes, Reactive - Red 120 using macrofungus Pleurotus sp. and microfungus Aspergillus sp. will be investigated. 


\section{EXPERIMENTAL}

\subsection{Organisms}

Aspergillus sp. and Pleurotus sp. were obtained from Bio Research Lab UiTM Perlis. The fungi were isolated from contaminated soil collected from the plantation unit in UiTM Arau, Perlis. Both fungi were cultured on petri dish containing potato dextrose agar (PDA) and were subcultured periodically.

\subsection{Preparation of Minimal Salt Solution (MSS)}

A $2.0 \mathrm{~g}$ of $\mathrm{Na}_{2} \mathrm{HPO}_{4}, 0.71 \mathrm{~g}$ of $\mathrm{K}_{2} \mathrm{SO}_{4}, 4.0 \mathrm{~g}$ of $\mathrm{NH}_{4} \mathrm{HPO}_{4}, 0.53 \mathrm{~g}$ of $\mathrm{KH}_{2} \mathrm{PO}_{4}, 0.10 \mathrm{~g}$ of $\mathrm{MgSO}_{4} .7 \mathrm{H}_{2} \mathrm{O}$ were weighed for MSS preparation. After that, it was dissolved in $1000 \mathrm{ml}$ of distilled water. MSS served as a liquid media for fungi growth.

\subsection{Fungi growth experiment}

Each pure isolated fungus was selected in order to measure their growth with the presence of synthetic dye Reactive Red. The dye was added into $10 \mathrm{ml}$ MSS that was amended with streptomycin. In order to have a uniform concentration of dye in all tubes, the solutions were thoroughly mixed with magnetic stirrer, before tubing process. Two concentrations of Reactive Red dye and MSS mixture $10 \mathrm{mg} / \mathrm{L}$ and $20 \mathrm{mg} / \mathrm{L}$ were prepared. Pure MSS was prepared for control without addition of dye. All tubes were inoculated with $2 \times 0.5 \mathrm{~cm}$ diameter plugs of fungi mycelia from agar plate. The next step was the tubes were incubated at room temperature, $28 \pm 1{ }^{\circ} \mathrm{C}$. The test tubes were shaken constantly using orbital shaker at $130 \mathrm{rpm}$ throughout duration of experiment to facilitate dye-cell phase contact. The growth of fungus was measured every 3 days by using spectrophotometer at $540 \mathrm{~nm}$ for 21 days. Kinetic growth and percentage of growth were calculated using the following equation.

Kinetic growth for each phases $=\frac{A_{2}-A_{1}}{T_{2}-T_{1}}$

Percentage of growth at exponential $=\frac{\mathrm{K}_{\text {exponential }}}{\text { Total } \mathrm{K}} \times 100 \%$

where $\mathrm{A}_{1}=$ Initial Absorbance, $\mathrm{A}_{2}=$ Final Absorbance, $\mathrm{K}=$ Kinetic growth, $\mathrm{T}_{1}=$ Initial Time and $\mathrm{T}_{2}=$ Final Time.

\subsection{Decolorization of Synthetic Dye Reactive Red - 120}

In the preparation of $500 \mathrm{mg} / \mathrm{L}$ dye stock solution, MSS was used as the replacement of 
distilled water. The prepared dye stock solution was diluted into two different concentrations, $10 \mathrm{mg} / \mathrm{L}$ and $20 \mathrm{mg} / \mathrm{L}$. A $10 \mathrm{ml}$ of each concentration was measured into eight test tubes. Each type of the fungi was added into the test tubes and was plug with sterile cotton wool and wrapped with aluminium foil to ensure maximum aeration without cross contamination. Control was prepared. Then all the test tubes were incubated at room temperature $28{ }^{\circ} \mathrm{C}$ for 21 days. The test tubes were shaken constantly using an orbital shaker at $130 \mathrm{rpm}$ throughout the experiment to facilitate dye-cell phase contact. Sample was extracted by using centrifuge at $5000 \mathrm{rpm}$ for $10 \mathrm{~min}$ in order to eliminate fungi. The ability to decolorize dye and growth rate of the fungi in MSS were measured every 3 days using spectrophotometer. The wavelength used was $536 \mathrm{~nm}$ for dye degradation.

The experiment was repeated on the ability of fungi to decolorize synthetic dye at different pH. The selected $\mathrm{pH}$ were $\mathrm{pH} 5,7$ and 9. The percentage of decolorization was calculated using the following equation.

Decolorization $(\%)=\frac{\text { Contrcl }_{\mathrm{Abs}}-\text { Sample }_{\mathrm{Abs}}}{\text { Control }_{\mathrm{Abs}}} \times 100$

where Abs $=$ Absorbance.

\section{RESULTS AND DISCUSSION}

\subsection{Growth of Fungi in MSS}

Fig. 1 shows two types of fungi growth corresponded to sigmoid growth curve. Generally, there are three phases of fungi growth namely lag, exponential and stationary phases with different kinetics. From day 3 until day 6, all of the fungi at the early stage known as a lag with the kinetic of $0.009 \mathrm{abs} /$ day for Aspergillus sp. and $0.007 \mathrm{abs} /$ day for Pleurotus sp. (Table 1). At this phase, the fungi were adapting to the new environment and the growths were slow. The next phase was exponential phase that started from day 6 until 15, where the fungi effectively utilized the nutrient and grew rapidly. The Aspergillus sp. showed higher growth rate with $0.010 \mathrm{abs} /$ day compared to Pleurotus sp. at $0.008 \mathrm{abs} /$ day. The percentage of growth in exponential phase showed that Aspergillus sp. exhibited higher percentage at $9.90 \%$ when compared to Pleurotus sp. at $7.92 \%$. Fungi were at optimum level due to favourable and most susceptible environment conditions at this stage. From day 15 until 21, 
the fungi were at stationary phase as the death and reproduction rate were equal. The kinetic growth was low and negligible due to depletion of nutrients in their environment. Both fungi were healthy and able to growth in the liquid media. In conclusion, Aspergillus sp. showed higher growth rate compared to Pleurotus sp. in MSS.

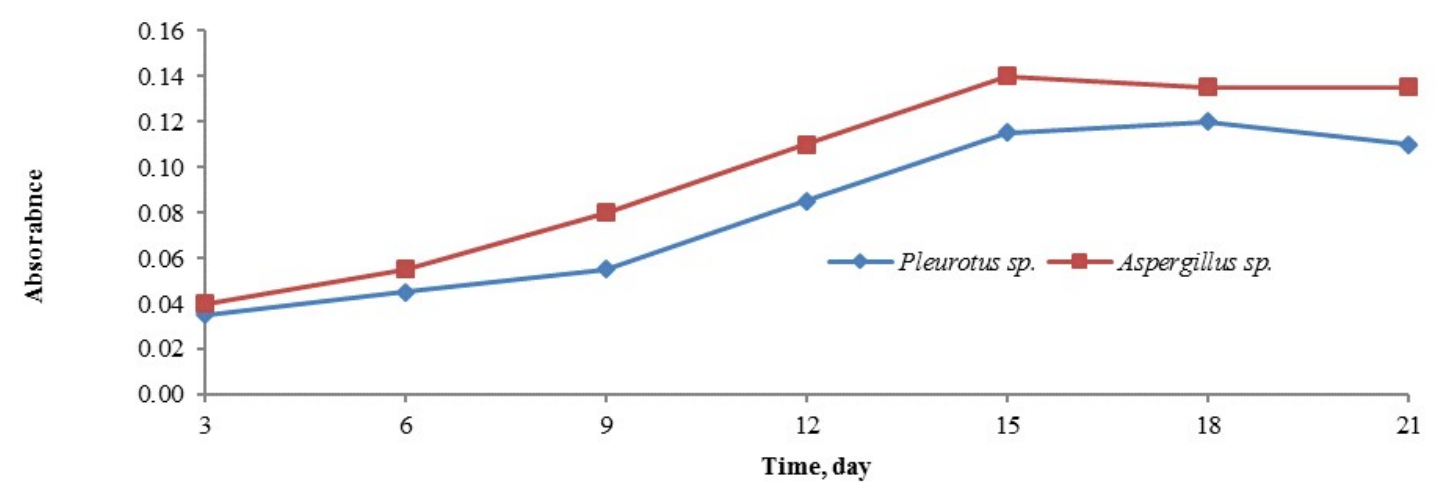

Fig.1. Sigmoid growth curve for two types of fungi in MSS

Table 1. Kinetic growth for lag, exponential and stationary phase and percentage of exponential phase

\begin{tabular}{ccc}
\hline $\begin{array}{c}\text { Phases in } \\
\text { Growth Curve }\end{array}$ & $\begin{array}{c}\text { Kinetic Growth of } \\
\text { Aspergillus sp. (Abs/Day) }\end{array}$ & $\begin{array}{c}\text { Kinetic Growth of } \\
\text { Pleurotus sp. (Abs/Day) }\end{array}$ \\
\hline Lag phase & 0.009 & 0.007 \\
Exponential phase & 0.010 & 0.008 \\
Stationary phase & 0.001 & 0.001 \\
Percentage for exponential phase & $9.90 \%$ & $7.92 \%$ \\
\hline
\end{tabular}

\subsection{Growth of Fungi in Different pH Values}

Fig. 2(a), Fig. 2(b), Table 2(a) and Table 2(b) show growths of Aspergillus sp. and Pleurotus sp. in different $\mathrm{pH}$ values of $\mathrm{pH} 5, \mathrm{pH} 7$ (unadjusted) and $\mathrm{pH}$ 9. The trends are similar for both fungi in growth rate and kinetic growth as shown in part A. The Aspergillus sp. and Pleurotus sp. showed the highest growth rate and kinetic in pH 5 under exponential phase. A 0.012 abs/day and $11.88 \%$ percentage of Aspergillus sp. growth and 0.009 abs/day for with $8.91 \%$ percentage of Pleurotus sp. growth were recorded. The growth rates of both fungi decreased as the $\mathrm{pH}$ values increased. This was due to low concentration of hydrogen ion decreased the degree of dissociation of the inorganic ion in the culture solution. Thus, low concentration of hydrogen ion limited the fungi growth. 


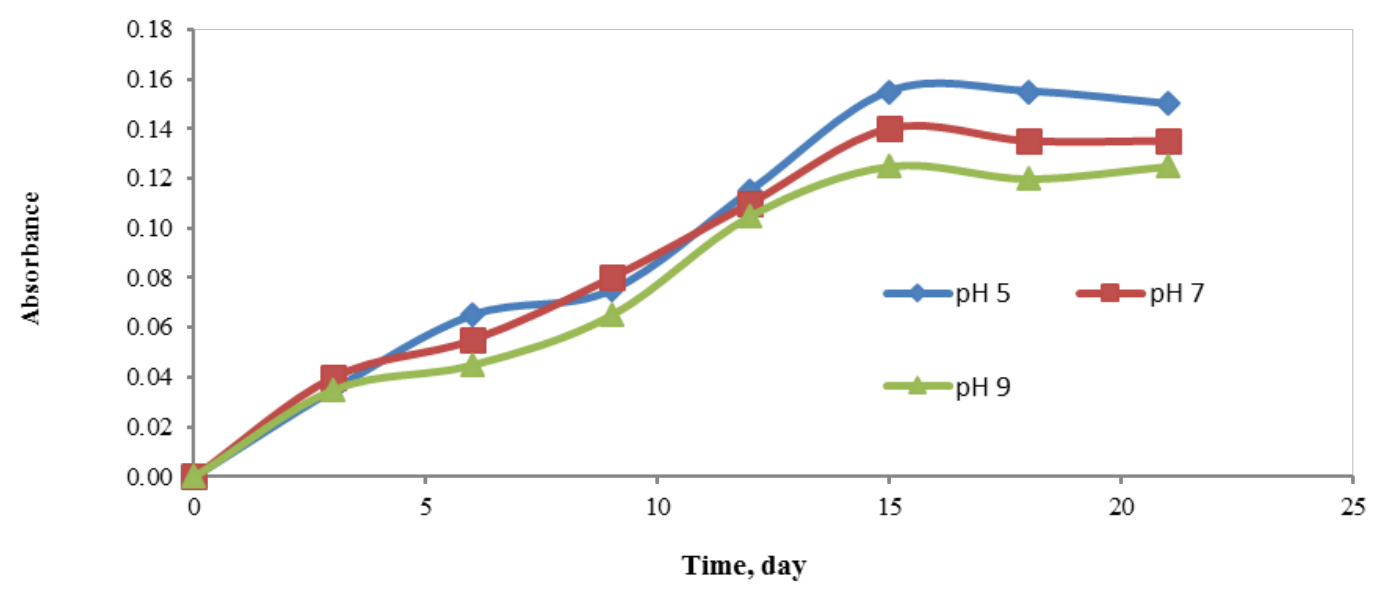

(a)

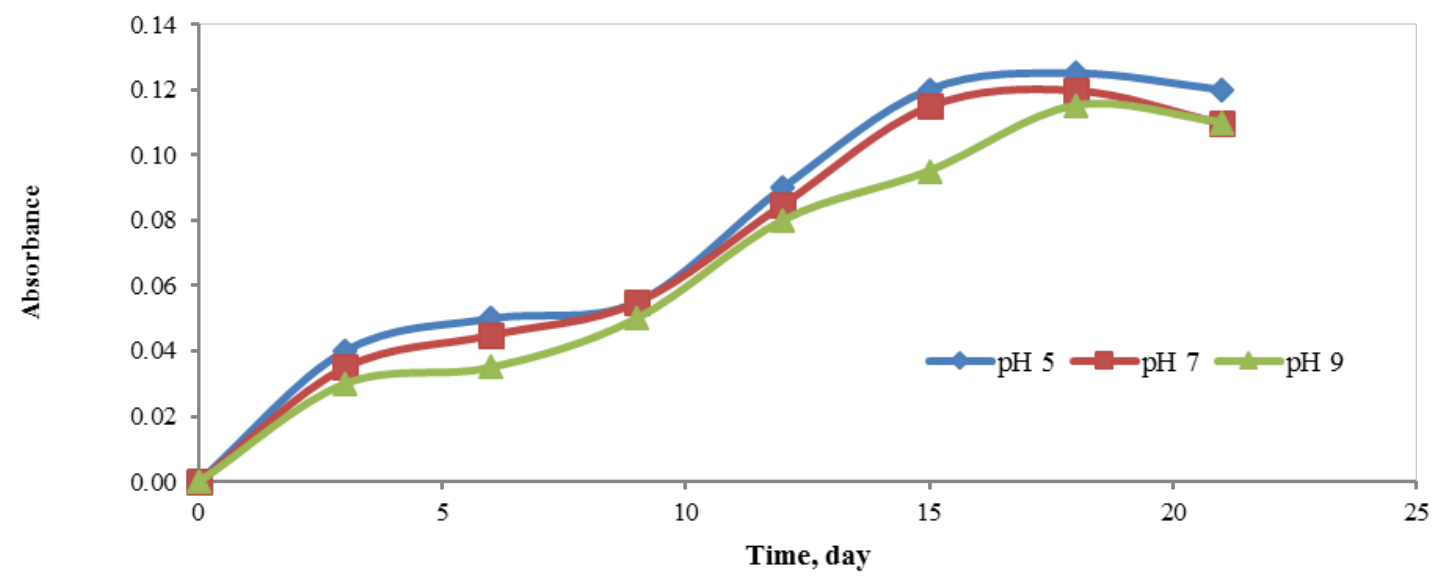

(b)

Fig.2. pH effect on fungi growth: (a) Aspergillus sp., (b) Pleurotus sp.

Table 2. Kinetic growth for lag, exponential, and stationary phase and percentage of exponential phase in different $\mathrm{pH}$

(a) Aspergillus sp.

\begin{tabular}{cccc}
\hline $\begin{array}{c}\text { Phase in } \\
\text { Growth Curve }\end{array}$ & $\begin{array}{c}\text { pH 5 } \\
\text { (Abs/Day) }\end{array}$ & $\begin{array}{c}\text { pH 7 } \\
\text { (Abs/Day) }\end{array}$ & $\begin{array}{c}\text { pH 9 } \\
\text { (Abs/Day) }\end{array}$ \\
\hline Lag phase & 0.005 & 0.0045 & 0.004 \\
Exponential phase & 0.012 & 0.010 & 0.009 \\
Stationary phase & 0.001 & 0.001 & 0.001 \\
Percentage for exponential phase & $11.88 \%$ & $9.90 \%$ & $8.9 \%$ \\
\hline
\end{tabular}

(b) Pleurotus sp. 


\begin{tabular}{cccc}
\hline $\begin{array}{c}\text { Phases in } \\
\text { Growth Curve }\end{array}$ & $\begin{array}{c}\text { pH 5 } \\
\text { (Abs/Day) }\end{array}$ & $\begin{array}{c}\text { pH 7 } \\
\text { (Abs/Day) }\end{array}$ & $\begin{array}{c}\text { pH 9 } \\
\text { (Abs/Day) }\end{array}$ \\
\hline Lag phase & 0.0045 & 0.004 & 0.003 \\
Exponential phase & 0.009 & 0.008 & 0.007 \\
Stationary phase & 0.001 & 0.001 & 0.001 \\
Percentage for exponential phase & $8.91 \%$ & $7.92 \%$ & $6.93 \%$ \\
\hline
\end{tabular}

\subsection{Effect of Dye Concentration on Decolorization of Synthetic Dye Reactive Red - 120}

Fig. 3(a) shows the effect of dye concentration on the decolorization of $10 \mathrm{mg} / \mathrm{L}$ and $20 \mathrm{mg} / \mathrm{L}$ by Aspergillus sp. for 21 days. It was observed that $10 \mathrm{mg} / \mathrm{L}$ concentration showed higher decolorization percentage $29 \%$ compared to $23 \%$ at $20 \mathrm{mg} / \mathrm{L}$ concentration of dye. Higher concentrations of dye were toxicant and harmful toward fungi. Low population of fungi reduced ligninolytic enzyme production. This leads to low decolorization percentage. In [9] reported similar observation on Aspergillus niger in degradation of Direct red dye.

Fig. 3(b) shows the decolorization at $10 \mathrm{mg} / \mathrm{L}$ and $20 \mathrm{mg} / \mathrm{L}$ dye concentration of Reactive Red - 120 by Pleurotus sp. for 21 days culture in the MSS. The decolorization percentage was higher in $10 \mathrm{mg} / \mathrm{L}$ concentration at $24 \%$ compared to $20 \mathrm{mg} / \mathrm{L}$ concentration at $17 \%$. The trend of Pleurotus sp. dye decolorization was similar to Aspergillus sp. However, Aspergillus sp. demonstrated higher rate of dye decolorization percentage compared to Pleurotus sp. at lower concentrations. This is because Aspergillus sp. produced Laccase, Lignin peroxidase (LiP) and tyrosinase which enhanced the degree of decolorization for reactive dyes when compared to Pleurotus sp. that only produced LiP enzyme in dye decolorization [10]. This result was supported by [11] who reported similar observation as this study on fungi Aspergillus niger, Penicillium sp. and Pleurotus ostreatus were used to decolorize Acid Red 73 and Reactive Blue - 109 dye.

In summary, dye decolorization percentage is associated with fungi growth. With increase in number of fungi cell, more ligninolytic enzymes are produced by the fungi and that lead to increase in the decolorization percentage. 


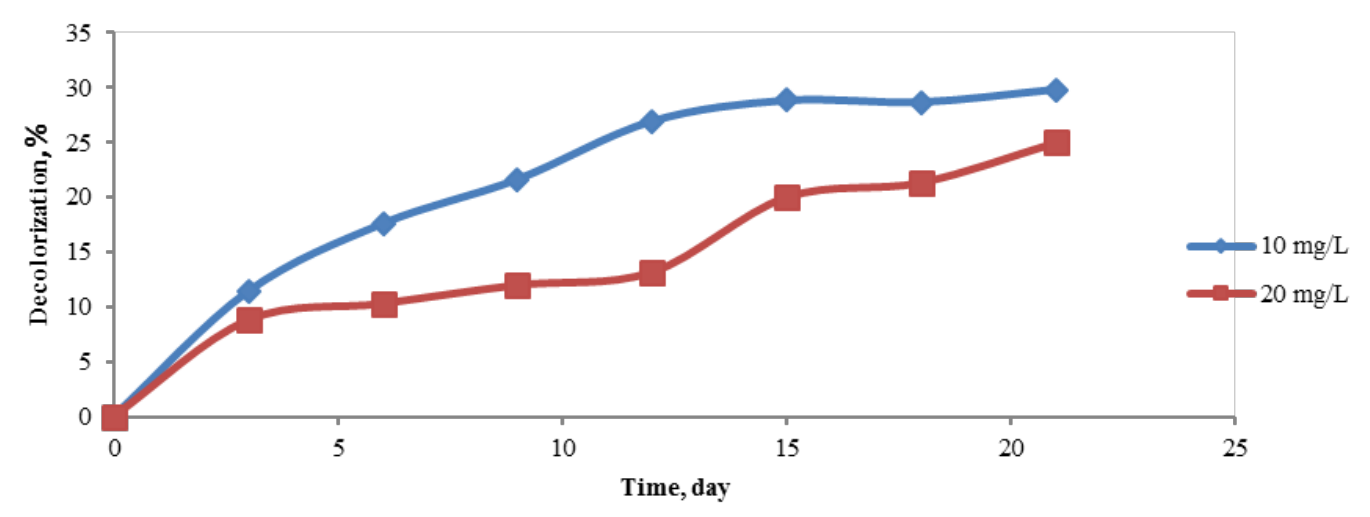

(a)

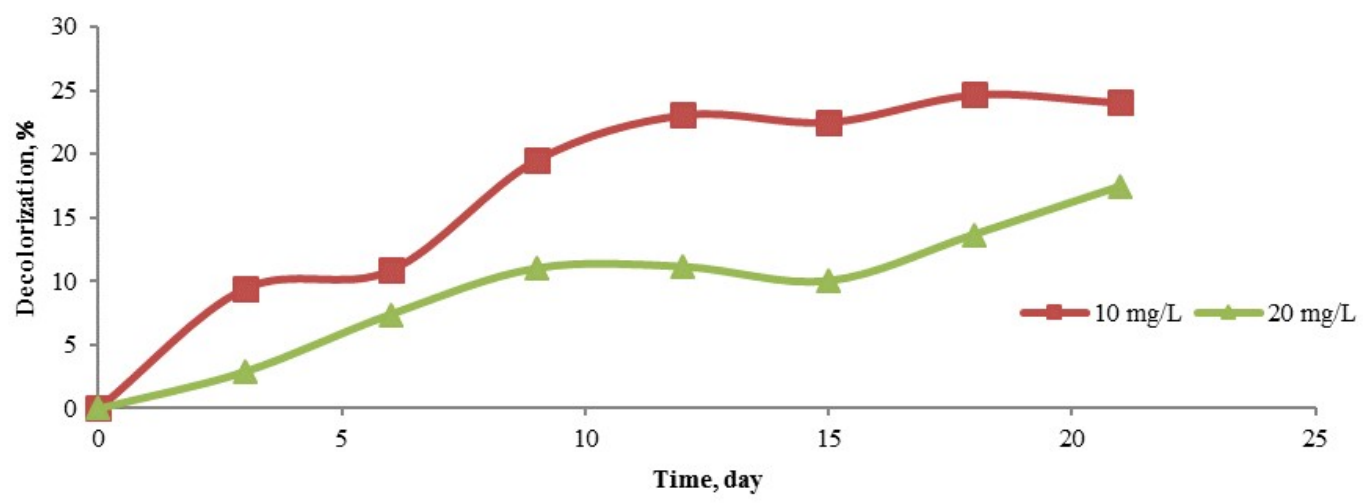

(b)

Fig.3. Effect of dye concentration on decolorization of synthetic dye Reactive Red -120 by fungi: (a) Aspergillus sp., (b) Pleurotus sp.

\subsection{Effect of $\mathrm{pH}$ on decolorization of synthetic dye Reactive Red - 120}

The decolorization at $\mathrm{pH} \mathrm{5,7}$ and 9 by Aspergillus sp. is shown in Fig. 4(a). The decolorization percentage of Reactive Red - 120 dyes for Aspergillus sp. at pH 5, 7 and 9 were $63 \%, 29 \%$ and $14 \%$ respectively. It was found that $\mathrm{pH} 5$ was the most effective in decolorization. This is due to Laccase synthesis is optimum at $\mathrm{pH} 5$ [1] and dye decolorization efficiency accordance to laccase enzyme production. Moreover, acidic condition promotes conformation changes in the ligninolytic enzyme's three-dimensional structure thus affecting the active site and increasing biocatalytic reactions. The results are supported by [4] who reported optimum $\mathrm{pH}$ was at $\mathrm{pH} 5$ in Reactive Blue -25 decolorization. This observation also supported section B where at higher growth rate, more new cells were produced and increased the amount of secreted ligninolytic enzymes. Hence, such circumstances increased the 
percentage of decolorization. Various studies also reported that the optimum ligninolytic enzyme production corresponded to dye decolorization performance in acidic $\mathrm{pH} 4$ to 6 [11-12].

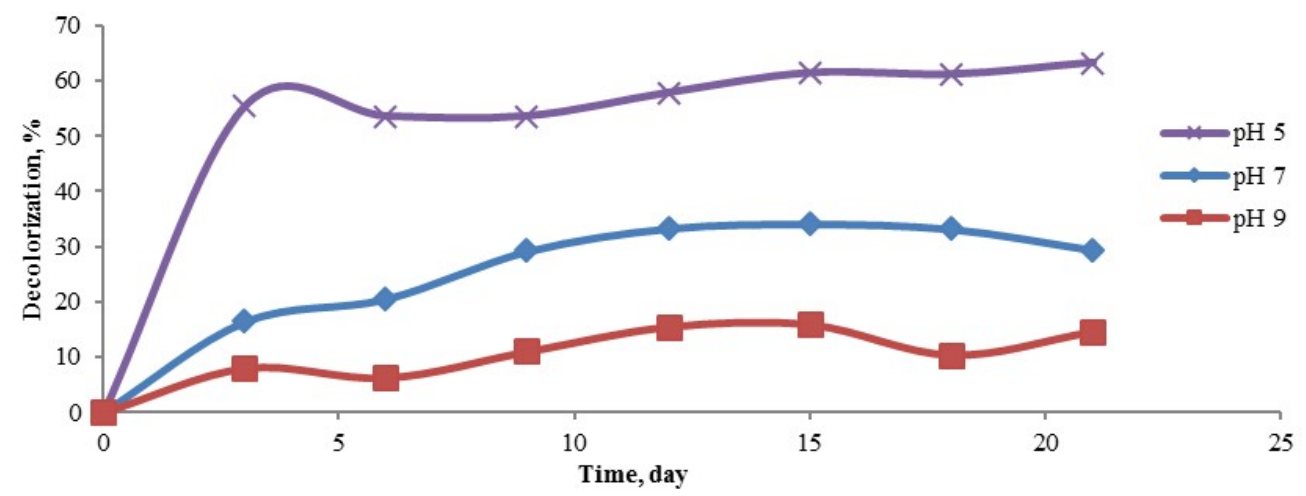

(a)

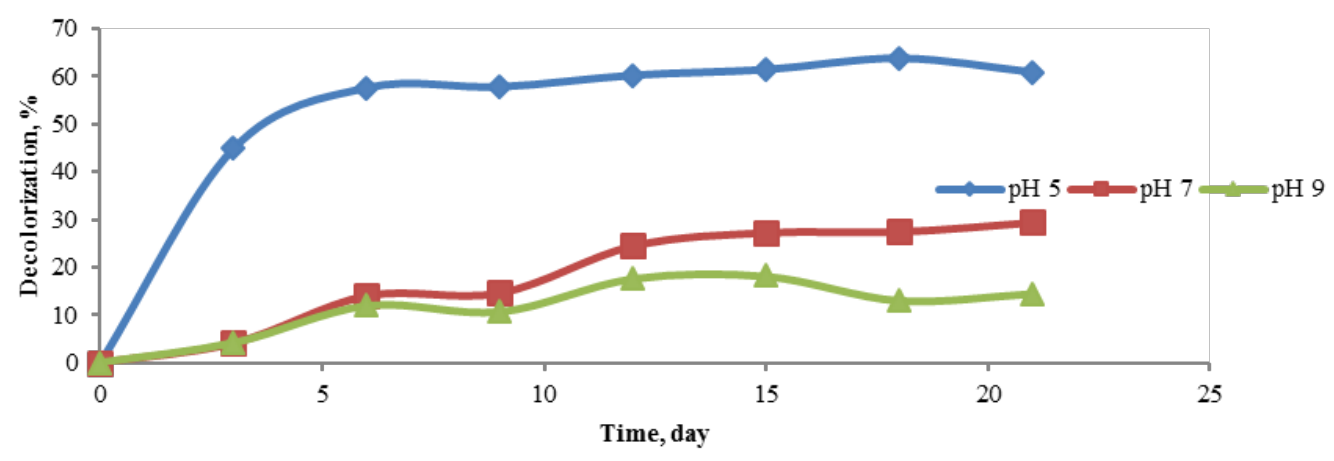

(b)

Fig.4. Effect of dye concentration on decolorization of synthetic dye Reactive-red - 120 by fungi: (a) Aspergillus sp., (b) Pleurotus sp.

The different $\mathrm{pH}$ used for the dye decolorization of Reactive Red - 120 by Pleurotus sp. at $\mathrm{pH}$ 5, 7 and 9 is shown in Fig. 4(b). The decolorization percentage of Reactive Red - 120 dyes for Pleurotus sp. with pH 5, 7 and 9 were $60 \%, 29 \%$ and $14 \%$ respectively. The most effective $\mathrm{pH}$ in decolorization was $\mathrm{pH}$ 5. The slowest fungi growth is at $\mathrm{pH} 9$ due to low concentration of hydrogen ion that limits fungi growth. Hydrogen ion concentrations control the degree of dissociation of the inorganic ion in the culture solution and affects growth of fungi. At $\mathrm{pH} 5$ with high hydrogen ion concentration, fungi performed the highest growth rate. With the high number of fungi cells, more ligninolytic enzyme were produced and thus it increased the decolorization percentage [13]. 


\section{CONCLUSION}

The study evaluates the ability of Pleurotus sp. and Aspergillus sp. in decolorization of synthetic dye Reactive Red -120 . The fungi were able to survive optimally and utilized the nutrient source from dye at $10 \mathrm{mg} / \mathrm{L}$ concentration. Decolorization of dye was highly effective under $\mathrm{pH} 5$ for both fungi. Aspergillus sp. showed significant difference where it has higher percentage of decolorization compared to Pleurotus sp. due to differences in types of ligninolytic produced. Aspergillus sp. produceds Laccase, Lignin peroxidase (LiP) and tyrosinase which enhanced the degree of decolorization for reactive dyes compared to Pleurotus sp. that only produced LiP enzyme in dye decolorization [4]. The result proposes that Aspergillus sp. is a better fungus for decolorization of Reactive Red - 120 compared to Pleurotus sp. This study contributes to the knowledge of mycoremediation and product of mycoremediation kit could be developed and applied in industry.

\section{ACKNOWLEDGEMENTS}

We acknowledge the financial support from Fundamental Research Grant Scheme (IRAGS) 600-RMI/IRAGS 5/3 (53/2015) and facilities support from Universiti Teknologi MARA.

\section{REFERENCES}

[1] Balan D S L, Monteiro R T M. Decolorization of textile indigo dye by ligninolytic fungi. Journal of Biotechnology, 2001, 89(2):141-145

[2] Singh M, Srivastava P K, Verma P C, Kharwar R N, Singh N, Tripathi R D. Soil fungi for mycoremediation of arsenic pollution in agriculture soils. Journal of Applied Microbiology, 2015, 119(5):1278-1290

[3] Singh L, Singh V P. Biodegradation of textile dyes, bromophenol blue and Congo red by fungus Aspergillus flavus. Environment and We an International Journal of Science and Technology, 2010, 5:235-242

[4] Parshetti G K, Kalme S D, Gomare S S, Govindwar S P. Biodegradation of Reactive blue-25 by Aspergillus ochraceus NCIM-1146. Bioresource Technology, 2007, 98(18):3638-3642

[5] Hartikainen E S, Miettinen O, Hatakka A, Kähkönen M A. Decolorization of six synthetic 
dyes by fungi. American Journal of Environmental Sciences, 2016, 12(2):77-85

[6] O'mahony T, Guibal E, Tobin J M. Reactive dye biosorption by Rhizopus arrhizus biomass. Enzyme and Microbial Technology, 2002, 31(4):456-463

[7] Zheng Z, Levin R E, Pinkham J L, Shetty K. Decolorization of polymeric dyes by a novel Penicillium isolate. Process Biochemistry, 1999, 34(1):31-37

[8] Fu Y, Viraraghavan T. Fungal decolorization of dye wastewaters: A review. Bioresource Technology, 2001, 79(3):251-262

[9] Mohan G. Logambal K, Ravikumar R, Investigation on the removal of direct RED dye using Aspergillus Niger and Aspergillus Flavus under static and shaking condition with modeling. International Journal of Science, Environment and Technology, 2012, 1(3):144-153 [10] Ali N F, El-Mohamedy R S. Cationization of cotton fabric for dyeing with natural anthraquinone dyes from fusarium oxysporum. Research Journal of Textile and Apparel, 2010, $14(2): 21-29$

[11] Ramya M, Anusha B, Kalavathy S, Devilaksmi S. Biodecolorization and biodegradation of Reactive Blue by Aspergillus sp. African Journal of Biotechnology, 2007, 6(12):1441-1445

[12] Erum S, Ahmed S. Comparison of dye decolorization efficiencies of indigenous fungal isolates. African Journal of Biotechnology, 2011, 10(17):3399-3411

[13] Plácido J, Chanagá X, Ortiz-Monsalve S, Yepes M, Mora A. Degradation and detoxification of synthetic dyes and textile industry effluents by newly isolated Leptosphaerulina sp. from Colombia. Bioresources and Bioprocessing, 2016, 3(1):1-14

\section{How to cite this article:}

Ibrahim N N, Talib S A, Ismail H N, Tay C C. Decolorization of reactive red-120 by using macrofungus and microfungus. J. Fundam. Appl. Sci., 2017, 9(6S), 954-964. 